\title{
How context influences the tactical-technical behavior of learners: the case of volleyball
}

\section{Como o contexto influencia o comportamento técnico e tático de aprendizes: o caso do voleibol}

\author{
Augusto Cézar Rodrigues Rocha ${ }^{1}$ \\ (D) https://orcid.org/0000-0003-3583-5676 \\ Auro Barreiros Freire ${ }^{2}$ \\ (iD) https://orcid.org/0000-0001-5198-9363 \\ Alcilas Borges da Silva Junior ${ }^{1}$ \\ (D) https://orcid.org/0000-0003-2659-0654 \\ Leonardo Rodrigues Martins \\ (D) https://orcid.org/0000-0001-8224-3177 \\ Mariana Pereira Maia ${ }^{1}$ \\ (D) https://orcid.org/0000-0003-4763-4994 \\ Gustavo Palhares Mitre ${ }^{3}$ \\ (D) https://orcid.org/0000-0002-8330-9518 \\ Henrique de Oliveira Castro ${ }^{4}$ \\ (D) https://orcid.org/0000-0002-0545-164X \\ Gustavo De Conti Teixeira Costa \\ (i) https://orcid.org/0000-0003-0911-8753
}

Abstract - This study compared the tactical-technical behavior between two distinct situations of reduced volleyball games. The sample consisted of 12 games played by doubles, 6 of which were played in $3.0 \mathrm{~m} \times 3.0 \mathrm{~m}$ (SIT1) and 6 of $2.0 \mathrm{~m} \times 4.5 \mathrm{~m}$ (SIT2) courts. Thus, the behavior of 12 participants, with mean age of $16.7 \pm 1.5$ years and $3.2 \pm 1.2$ years of practice, was compared. The results showed that at reception, better results were obtained in adjustment and decision making in SIT2, whereas in SIT1, efficiency was higher; in setting, it was observed that SIT2 presented better results in technical performance, adjustment and efficiency, whereas in SIT1, efficiency was higher; in SIT2, attack, better results were observed in adjustment and decision-making. It was concluded that environmental restrictions influence the behaviors of learners, showing that different ecological contexts provide actions inherent to the specific game environment.

Key words: Efficiency; Learning; Volleyball.

Resumo - O estudo comparou o comportamento tático-técnico entre duas situaçôes distintas de jogos reduzidos no voleibol. A amostra constituiu-se de 12 jogos disputados por duplas, sendo 6 praticados em quadras de 3,0m $\times 3,0 m$ (SIT1) e 6 de 2,0m $\times 4,5 m$ (SIT2). Assim, comparou-se o comportamento de 12 participantes, com idade média de 16,7 $\pm 1,5$ anos e com $3,2 \pm 1,2$ anos de prática. Os resultados mostraram que na recepção houve melhores resultados no ajustamento e na tomada de decisão na SIT2, enquanto que na SIT1 a eficácia foi mais elevada; no levantamento observou-se que a SIT2 apresentou melhores resultados no desempenho técnico, ajustamento e eficiência, enquanto que na SIT1 a eficácia foi mais elevada; no ataque, na SIT2, observou-se melhores resultados no ajustamento e na tomada de decisão. Conclui-se que as restrições ambientais influenciam nos comportamentos dos aprendizes, evidenciando que contextos ecológicos diferentes oportunizam açôes inerentes ao ambiente especifico de jogo.

Palavras-chave: Aprendizagem; Eficiência; Voleibol.
1 Universidade Federal de Goiás. Goiânia, GO. Brazil.

2 Centro Universitário Una de Belo Horizonte. Belo Horizonte, MG. Brazil.

3 Centro Universitário Estácio de Belo Horizonte. Belo Horizonte, MG. Brazil.

4 Centro Universitário Estácio de Brasilia. Taguatinga, DF. Brazil.

Received: September 29, 2018 Accepted: April 11, 2019

How to cite this article Rocha ACR, Freire AB, Silva Junior $A B$, Martins LR, Maia MP, Mitre GP, Castro HO, Costa GCT. How context influences the tactical-technical behavior of learners: the case of volleyball. Rev Bras Cineantropom Desempenho Hum 2020, 22:e59461. D0I: http://dx.doi. org/10.1590/1980-0037.2020v22e59461

Copyright: This work is licensed under a Creative Commons Attribution 4.0 International License. 


\section{INTRODUCTION}

Studies on small-sided games (SSGs) in various sports have shown that reducing the number of players is a common strategy in invasion games and aim to reduce the attention demands of players ${ }^{1}$, to increase the amount of tactical-technical actions performed by players ${ }^{2}$, consequently allowing players to gain more tactical experience in situational contexts ${ }^{3,4}$. Moreover, research in this area shows that there are differences in tactical-technical behavior according to invasion sports such as soccer ${ }^{5-7}$, basketball $^{8}$, handball ${ }^{9}$, hockey ${ }^{10}$ among others, as they are organized by their respective specificities.

In this context, it was observed that in soccer, reduced games provide offensive sequences with greater ball circulation, according to athletes' experience ${ }^{3}$, and the manipulation of the court size and number of players changes the technical-tactical demand according to the objectives of training sessions ${ }^{4,5}$. Thus, the manipulation of task constraints such as number of players and court size changes the likelihood of the occurrence of emerging tactical behaviors, as well as exploration in different regions of the court searching for the solution for tasks ${ }^{6}$. In addition, it was observed that in basketball, adaptations of rules are necessary to achieve different tactical goals; while in hockey, the reduction in the number of players allows increasing the performance of sport-related skills, suggesting that the court size allows the improvement of technical skills and timely decision-making regarding environmental restrictions ${ }^{10}$.

However, it is not clear how tactical behaviors, specifically how task constraints change $\mathrm{e}^{11}$, and studies on this topic about volleyball are scarce in literature. Thus, the aim of the present study was to compare the tacticaltechnical behavior on the side-out (reception, setting and attacking), due to its high efficacy ${ }^{12,13}$, between two distinct situations of reduced volleyball games.

\section{METHOD}

\section{Sample}

The sample consisted of 12 games, totaling 227 receptions, 191 settings and 216 attacks, from which the tactical-technical behavior of 12 participants with average age of $16.7 \pm 1.5$ years and $3.2 \pm 1.2$ years of practice and participants of the Goiás Youth Male Volleyball Team was compared. This research followed recommendations of the Research Ethics Committee and was approved according to protocol number 1.986.220 of the Federal University of Goiás.

\section{Design}

Athletes were divided into pairs, and the highest ranked athlete paired with the worst ranked athlete and so on. Ranking was performed by three experienced volleyball coaches and the participants' technical and tactical levels were considered. For this study, the definition proposed by Erickson et al. ${ }^{14}$ was adopted. 
Each pair played two games on the first day of intervention with minimum interval of 10 minutes and the second day of intervention occurred after a $48 \mathrm{~h}$ interval in which each pair played two more games with the same interval and respecting the same sequence of games, totaling twelve games. Games took place on $9 \mathrm{~m} 2$ courts with different configurations. On the first day, situation 1 (SIT1) occurred on court with dimensions of $3.0 \mathrm{~m} \times 3.0 \mathrm{~m}$ (Figure 1-a), while the second day, situation 2 (SIT2) occurred on court with dimensions of $2.0 \mathrm{~m} \times 4.5 \mathrm{~m}$ (Figure 1-b).

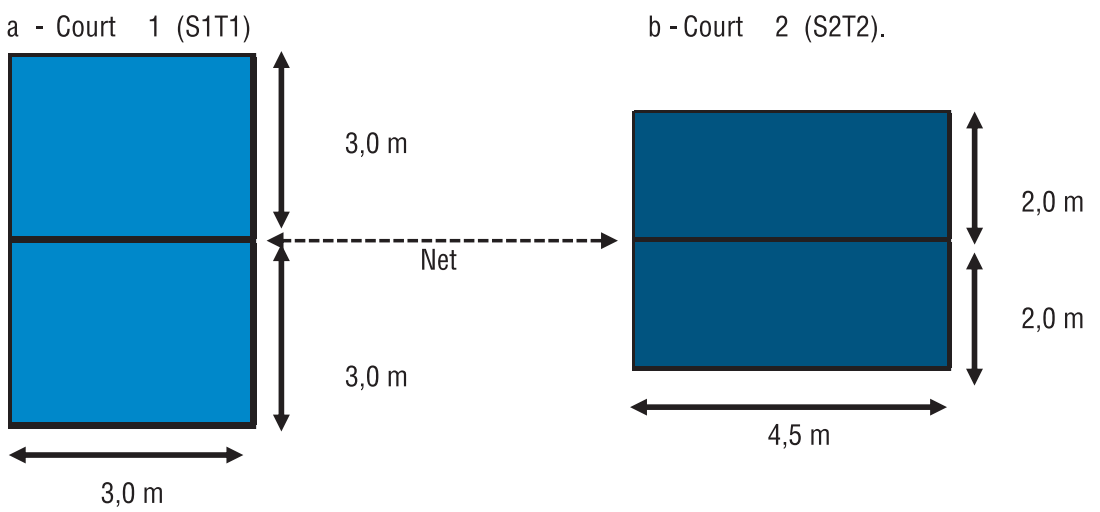

Figure 1. Dimensions of playing courts

\section{Tactical-technical behavior assessment}

In order to evaluate participants' tactical and technical behavior, the instrument validated by Collet et al. ${ }^{15}$ was used, and reception, set and attack fundamentals were analyzed, according to performance components related to efficiency, effectiveness, decision making and adjustment. Thus, in the reception evaluation, indicators were determined taking into account the objective of recovering the ball for attack construction. In the setting evaluation, it was sought to contemplate the main action elements, considering the ideal conditions to perform the set movement and the attack evaluation, which are elements that determine the success in returning the ball to the opponent court. According to Porath et $a .^{16}$, the performance analysis observation criteria are based on the following: efficiency - characterized by the execution of technical skill; effectiveness - result obtained in the execution of skills; adjustment - stages of preparation for action and decision making - decision possibilities in each action.

\section{Data Collection Procedure}

Games were filmed by four cameras arranged at ground level, one on each side of the court and at a distance of 3 meters from the boundary lines of the court. Sony cameras with 1080p HD definition and frequency rate of 60 $\mathrm{Hz}$ were used. Collection was performed by four researchers who collected images for further analysis and afterwards, 2 of them were responsible for replacing the ball each time the point occurred, 1 for refereeing the game and 1 for timing the match time. 


\section{Statistical Procedures}

For descriptive analysis of data, data were used in frequencies, percentages, means and standard deviations. Game situations were compared by the Student's t-test to assess athletes' performance, and the chi-square (x2) and power of the phi effect $(\phi)$ were used to analyze categorical variables, and the significance value in both cases was $\mathrm{p}<0.05$. To calculate reliability, $30 \%$ of actions were reanalyzed, exceeding the reference value of $10 \%{ }^{17}$ and intra-observer values were between 0.90 and 0.98 and inter-observer values between 0.88 and 0.98 . Data were analyzed in the Statistical Package Social Science software (SPSS).

\section{RESULTS}

Results were presented according to fundamentals reception, setting and attack. On reception, the t-test for independent samples showed difference in item $1[\mathrm{t}(178.38)=-6.704 ; \mathrm{p}<0.05]$ and item $2[\mathrm{t}(225)=-3.951$; $\mathrm{p}<0.05$ ] of the adjustment in relation to the game situation (table 1). Thus, in the $4.5 \mathrm{~m} \times 2.0 \mathrm{~m}$ situation, athletes moved to occupy the position in the space where the ball was more likely to fall (item 1) and placed themselves in a position of expectation and adjusted their position according to the proximity of side lines (item 2) more often than in the $3.0 \mathrm{~m} \times 3.0 \mathrm{~m}$ situation. The t-test for independent samples showed no difference in reception efficiency in relation to the game situation.

Table 1. Analysis of reception in relation to the game situation

\begin{tabular}{|c|c|c|c|c|c|}
\hline & & Aspects analyzed & Situation & Mean \pm SD & $P$ \\
\hline \multirow{12}{*}{ Reception } & \multirow{6}{*}{ Adjustment } & \multirow{2}{*}{$\begin{array}{l}\text { Player moves to occupy position where the ball is } \\
\text { more likely to fall (item 1) }\end{array}$} & $3.0 \mathrm{~m} \times 3.0 \mathrm{~m}$ & $0.14 \pm 0.35$ & \multirow{2}{*}{$0.001^{*}$} \\
\hline & & & $4.5 \mathrm{~m} \times 2.0 \mathrm{~m}$ & $0.53 \pm 0.50$ & \\
\hline & & \multirow{2}{*}{$\begin{array}{l}\text { Player is in expectation position and adjust } \\
\text { his position according to the proximity of the } \\
\text { sidelines (left foot forward when closer to the line } \\
\text { on his left or right foot forward when closer to the } \\
\text { line on his right) (item 2). }\end{array}$} & $3.0 \mathrm{~m} \times 3.0 \mathrm{~m}$ & $0.34 \pm 0.48$ & \multirow[b]{2}{*}{$0.001^{*}$} \\
\hline & & & $4.5 \mathrm{~m} \times 2.0 \mathrm{~m}$ & $0.60 \pm 0.48$ & \\
\hline & & \multirow{2}{*}{$\begin{array}{l}\text { After receiving, player moves to perform the next } \\
\text { action (attack or cover) (item 3) }\end{array}$} & $3.0 \mathrm{~m} \times 3.0 \mathrm{~m}$ & $0.65 \pm 0.48$ & \multirow{2}{*}{0.256} \\
\hline & & & $4.5 \mathrm{~m} \times 2.0 \mathrm{~m}$ & $0.72 \pm 0.45$ & \\
\hline & \multirow{6}{*}{ Efficiency } & \multirow{2}{*}{$\begin{array}{l}\text { Lower limbs are semi-flexed and flat on the floor } \\
\text { at the moment of contact (item 1). }\end{array}$} & $3.0 \mathrm{~m} \times 3.0 \mathrm{~m}$ & $0.82 \pm 0.38$ & \multirow{2}{*}{0.617} \\
\hline & & & $4.5 \mathrm{~m} \times 2.0 \mathrm{~m}$ & $0.85 \pm 0.36$ & \\
\hline & & \multirow{2}{*}{$\begin{array}{l}\text { Player positions the body behind the ball and con- } \\
\text { tacts the ball in the middle of supports (item 2). }\end{array}$} & $3.0 \mathrm{~m} \times 3.0 \mathrm{~m}$ & $0.94 \pm 0.23$ & \multirow{2}{*}{0.387} \\
\hline & & & $4.5 \mathrm{~m} \times 2.0 \mathrm{~m}$ & $0.91 \pm 0.28$ & \\
\hline & & \multirow{2}{*}{$\begin{array}{l}\text { Contacts the ball on the forearm platform with the } \\
\text { upper limbs in extension (forearm pass) or con- } \\
\text { tacts the ball above and in front of the forehead } \\
\text { (touch) level (item 3). }\end{array}$} & $3.0 \mathrm{~m} \times 3.0 \mathrm{~m}$ & $0.98 \pm 0.15$ & \multirow[b]{2}{*}{0.793} \\
\hline & & & $4.5 \mathrm{~m} \times 2.0 \mathrm{~m}$ & $0.98 \pm 0.14$ & \\
\hline
\end{tabular}

Note * Difference found for $p<0.05$.

The inferential analysis of data through the chi-square test showed that there was association ( $\mathrm{x} 2=14.57 ; \mathrm{p}<0.001 ; \phi=0.25)$ between decision making at reception and game situation (table 1). It was observed that there was positive association of decision making item 2 (keep the ball in play 
in the team itself, but without direction) with game played in the $3.0 \mathrm{~m}$ $\mathrm{x} 3.0 \mathrm{~m}$ court and item 3 (anticipates and directs the ball into the setting zone) with game played on the $4.5 \mathrm{~m} \times 2.0 \mathrm{~m}$ court. On the other hand, there was negative association between item 2 and game played on the $4.5 \mathrm{~m} \times 2.0 \mathrm{~m}$ court and item 3 with game played on the $3.0 \mathrm{~m} \times 3.0 \mathrm{~m}$ court. The inferential analysis of data by means of the chi-square test showed that there was association $(\mathrm{x} 2=5.83 ; \mathrm{p}<0.05 ; \phi=0.16)$ between reception effectiveness and game situation (table 2). It was found that there was positive association of item 2 (continuity) with game played on the $4.5 \mathrm{~m}$ x $2.0 \mathrm{~m}$ court and item 3 (excellent reception or point when sending the ball to the opposing court) with game played on the $3.0 \mathrm{~m} \times 3.0 \mathrm{~m}$ court. However, there was negative association between item 2 with $3.0 \mathrm{~m} \times 3.0 \mathrm{~m}$ court game and item 3 with the $4.5 \mathrm{~m} \times 2.0 \mathrm{~m}$ court game.

Table 2. Decision making and reception effectiveness according to game situation

\begin{tabular}{|c|c|c|c|c|c|}
\hline & & & Situ & & \\
\hline & & & $\begin{array}{c}3.0 \mathrm{~m} x \\
3.0 \mathrm{~m}\end{array}$ & $\begin{array}{c}4.5 \mathrm{mx} \\
2.0 \mathrm{~m}\end{array}$ & Total \\
\hline & & Occurred & 3 & 3 & 6 \\
\hline & & Expected & 3.3 & 2.7 & 6.0 \\
\hline & Send the ball directly to the opposing court. & $\% \mathrm{DM}$ in reception & $50.0 \%$ & $50.0 \%$ & $100.0 \%$ \\
\hline & & $\%$ Situation & $2.4 \%$ & $2.9 \%$ & $2.6 \%$ \\
\hline & & Adjusted residue & -.2 & .2 & \\
\hline & & Occurred & 85 & 46 & 131 \\
\hline & & Expected & 71.0 & 60.0 & 131.0 \\
\hline Decision Making in & Keep the ball in play on the team itself but & $\% \mathrm{DM}$ in reception & $64.9 \%$ & $35.1 \%$ & $100.0 \%$ \\
\hline & & $\%$ Situation & $69.1 \%$ & $44.2 \%$ & $57.7 \%$ \\
\hline & & Adjusted residue & $3.8^{*}$ & $-3.8^{\star}$ & \\
\hline & & Occurred & 35 & 55 & 90 \\
\hline & & Expected & 48.8 & 41.2 & 90.0 \\
\hline & Anticipate and direct the ball to the setting & $\% \mathrm{DM}$ in reception & $38.9 \%$ & $61.1 \%$ & $100.0 \%$ \\
\hline & & $\%$ Situation & $28.5 \%$ & $52.9 \%$ & $39.6 \%$ \\
\hline & & Adjusted residue & $-3.7^{\star}$ & $3.7^{*}$ & \\
\hline Total & & Occurred & 123 & 104 & 227 \\
\hline rotal & & $\% \mathrm{DM}$ in reception & $54.2 \%$ & $45.8 \%$ & $100.0 \%$ \\
\hline & & Occurred & 3 & 4 & 7 \\
\hline & & Expected & 3.8 & 3.2 & 7,0 \\
\hline & Error. & $\%$ Reception effectiveness & $42.9 \%$ & $57.1 \%$ & $100.0 \%$ \\
\hline & & $\%$ Situation & $2.4 \%$ & $3.8 \%$ & $3.1 \%$ \\
\hline & & Adjusted residue & -6 & .6 & \\
\hline & & Occurred & 79 & 80 & 159 \\
\hline & & Expected & 86.2 & 72.8 & 159.0 \\
\hline Reception & Continuity. & $\%$ Reception effectiveness & $49.7 \%$ & $50.3 \%$ & $100.0 \%$ \\
\hline & & $\%$ Situation & $64.2 \%$ & $76.9 \%$ & $70.0 \%$ \\
\hline & & Adjusted residue & $-2.1^{*}$ & $2.1^{*}$ & \\
\hline & & Occurred & 41 & 20 & 61 \\
\hline & & Expected & 33.1 & 27.9 & 61.0 \\
\hline & $\begin{array}{l}\text { Excellent Reception or point when sending the } \\
\text { ball to the opposina court }\end{array}$ & $\%$ Reception effectiveness & $67.2 \%$ & $32.8 \%$ & $100.0 \%$ \\
\hline & & $\%$ Situation & $33.3 \%$ & $19.2 \%$ & $26.9 \%$ \\
\hline & & Adjusted residue & $2.4^{*}$ & $-2.4^{\star}$ & \\
\hline & & Occurred & 123 & 104 & 227 \\
\hline & & $\%$ Reception effectiveness & $54.2 \%$ & $45.8 \%$ & $100.0 \%$ \\
\hline
\end{tabular}

Note * Difference found for $p<0.05$. 
In setting, the t-test for independent samples showed that there was difference in item 1 [ $\mathrm{t}(144.88)=-6.96 ; \mathrm{p}<0.05]$ of the adjustment in relation to game situation (table 3 ). Thus, in the $4.5 \mathrm{~m} \times 2.0 \mathrm{~m}$ situation, athletes moved quickly to the setting position (item 1) more often than in the $3.0 \mathrm{~m}$ $\mathrm{x} 3.0 \mathrm{~m}$ situation. By analyzing the setting efficiency, the t-test for independent samples showed that there was difference in item $2[\mathrm{t}(144.88)=$ $-4.75 ; \mathrm{p}<0.05]$ in relation to the game situation (table 3 ). Thus, in the $4.5 \mathrm{~m}$ $\mathrm{x} 2.0 \mathrm{~m}$ situation, athletes coordinated flexion and extension of the upper and lower limbs (item 2) more often than in the $3.0 \mathrm{~m} \times 3.0 \mathrm{~m}$ situation.

Table 3. Comparison of adjustment and setting efficiency in relation to game situation

\begin{tabular}{|c|c|c|c|c|c|}
\hline & & Aspects analyzed & Situation & Mean \pm SD & $p$ \\
\hline \multirow{12}{*}{$\begin{array}{l}\text { Setting } \\
\text { Efficiency }\end{array}$} & \multirow{4}{*}{$\begin{array}{l}\text { Adjustment } \\
\text { Adjusts body position according to the ball } \\
\text { trajectory (item 2). }\end{array}$} & $\begin{array}{l}\text { Quickly moves to the set- } \\
\text { ting position (item 1). }\end{array}$ & $3.0 \mathrm{~m} \times 3.0 \mathrm{~m}$ & $0.11 \pm 0.31$ & $0.001^{*}$ \\
\hline & & $4.5 \mathrm{~m} \times 2.0 \mathrm{~m}$ & $0.55 \pm 0.52$ & & \\
\hline & & $3.0 \mathrm{~m} \times 3.0 \mathrm{~m}$ & $0.99 \pm 0.10$ & 0.341 & \\
\hline & & $4.5 \mathrm{~m} \times 2.0 \mathrm{~m}$ & $1.00 \pm 0.00$ & & \\
\hline & \multirow{2}{*}{$\begin{array}{l}\text { Stabilizes body position according to the } \\
\text { attack completion zone (setting at the fron- } \\
\text { tal plane) (item 3). }\end{array}$} & $3.0 \mathrm{~m} \times 3.0 \mathrm{~m}$ & $0.78 \pm 0.42$ & \multirow[t]{2}{*}{0.708} & \\
\hline & & $4.5 \mathrm{~m} \times 2.0 \mathrm{~m}$ & $0.80 \pm 0.40$ & & \\
\hline & \multirow{2}{*}{$\begin{array}{l}\text { Contacts the ball on the forearm platform } \\
\text { with the extended upper limbs (forearm } \\
\text { pass) or contacts the ball above and in } \\
\text { front of the forehead (touch) level (item 1). }\end{array}$} & $3.0 \mathrm{~m} \times 3.0 \mathrm{~m}$ & $0.97 \pm 0.17$ & \multirow[t]{2}{*}{0.147} & \\
\hline & & $4.5 \mathrm{~m} \times 2.0 \mathrm{~m}$ & $0.92 \pm 0.27$ & & \\
\hline & \multirow{2}{*}{$\begin{array}{l}\text { Coordinates flexion and extension of the } \\
\text { upper and lower limbs (item 2). }\end{array}$} & $3.0 \mathrm{~m} \times 3.0 \mathrm{~m}$ & $0.22 \pm 0.42$ & \multirow[t]{2}{*}{$0.001^{*}$} & \\
\hline & & $4.5 \mathrm{~m} \times 2.0 \mathrm{~m}$ & $0.54 \pm 0.50$ & & \\
\hline & \multirow{2}{*}{$\begin{array}{l}\text { At the moment of contact, moves the body } \\
\text { position to the attack completion zone } \\
\text { (item 3). }\end{array}$} & $3.0 \mathrm{~m} \times 3.0 \mathrm{~m}$ & $0.83 \pm 0.40$ & \multirow{2}{*}{0.927} & \\
\hline & & $4.5 \mathrm{~m} \times 2.0 \mathrm{~m}$ & $0.84 \pm 0.37$ & & \\
\hline
\end{tabular}

Note * Difference found for $p<0.05$.

Inferential analysis of data by the chi-square test showed that there was no association $(x 2=0.22 ; p>0.05 ; \phi=0.03)$ between decision making in setting and game situation. However, there was association $(x 2=9.38$; $\mathrm{p}<0.009 ; \phi=0.22$ ) between setting effectiveness and game situation. It was observed that there was positive association between continuity with game played on the $4.5 \mathrm{~m} \times 2.0 \mathrm{~m}$ court (3.0) and attack without block or single block with game played on the $3.0 \mathrm{~m} \times 3.0 \mathrm{~m}$ court (2.3). On the other hand, there was negative association of continuity with game played on the $3.0 \mathrm{~m} \times 3.0 \mathrm{~m}$ court $(-3.0)$ and attack without block or single block with game played on the $4.5 \mathrm{~m} \times 2.0 \mathrm{~m}$ court $(-2.3)$.

The attack analysis by the t-test for independent samples showed that there was difference in item 1 [ $\mathrm{t}(214)=-5.86 ; \mathrm{p}<0.05]$ of the adjustment in relation to game situation. Thus, in the $4.5 \mathrm{~m} \mathrm{x} 2.0 \mathrm{~m}$ situation, athletes waited for the setting to start the approach movement (item 1) more often than in the $3.0 \mathrm{~m} \times 3.0 \mathrm{~m}$ situation. However, the t-test for independent samples showed no difference in attack efficiency in relation to game situation.

Inferential analysis of data through the chi-square test showed that there was association $(\mathrm{x} 2=36.08 ; \mathrm{p}<0.001 ; \phi=0.41)$ between attack deci- 
sion making and game situation (Table 4). It was observed that there was positive association of item 1 (keeps the ball in play, but without direction) with game played on the $3.0 \mathrm{~m} \times 3.0 \mathrm{~m}$ court and item 2 (directs the ball for a particular player) with game played on the $4.5 \mathrm{~m} \times 2.0 \mathrm{~m}$ court. On the other hand, there was negative association between item 1 and game played on the $4.5 \mathrm{~m} \times 2.0 \mathrm{~m}$ court and item 2 with game played on the $3.0 \mathrm{~m}$ $x 3.0 \mathrm{~m}$ court. However, the inferential analysis of data through the chisquare test showed no association $(x 2=3.90 ; p>0.05 ; \phi=0.13)$ between attack effectiveness and game situation.

Table 4. Decision making in attack according to the game situation

\begin{tabular}{|c|c|c|c|c|c|}
\hline & & & \multicolumn{2}{|c|}{ Situation } & \multirow{2}{*}{ Total } \\
\hline & & & $3.0 \mathrm{~m} \times 3.0 \mathrm{~m}$ & $4.5 \mathrm{~m} \times 2.0 \mathrm{~m}$ & \\
\hline \multirow{15}{*}{$\begin{array}{l}\text { Decision making in } \\
\text { attack }\end{array}$} & \multirow{5}{*}{$\begin{array}{l}\text { Keeps the ball in play. but without } \\
\text { direction. }\end{array}$} & Occurred & 96 & 56 & 152 \\
\hline & & Expected & 80.2 & 71.8 & 152.0 \\
\hline & & $\%$ DM in attack & $63.2 \%$ & $36.8 \%$ & $100.0 \%$ \\
\hline & & $\%$ Situation & $84.2 \%$ & $54.9 \%$ & $70.4 \%$ \\
\hline & & Adjusted Residue & $4.7^{\star}$ & $-4.7^{\star}$ & \\
\hline & \multirow{5}{*}{$\begin{array}{l}\text { Directs the ball to a particular player } \\
\text { (collective tactic). }\end{array}$} & Occurred & 0 & 26 & 26 \\
\hline & & Expected & 13.7 & 12.3 & 26.0 \\
\hline & & $\%$ DM in attack & $0.0 \%$ & $100.0 \%$ & $100.0 \%$ \\
\hline & & $\%$ Situation & $0.0 \%$ & $25.5 \%$ & $12.0 \%$ \\
\hline & & Adjusted Residue & $-5.7^{\star}$ & $5.7^{*}$ & \\
\hline & \multirow{7}{*}{$\begin{array}{l}\text { Deflects the ball from the block by } \\
\text { attacking in the free space of the oppos- } \\
\text { ing court or exploit the block. }\end{array}$} & Occurred & 18 & 20 & 38 \\
\hline & & Expected & 20.1 & 17.9 & 38.0 \\
\hline & & $\%$ DM in attack & $47.4 \%$ & $52.6 \%$ & $100.0 \%$ \\
\hline & & $\%$ Situation & $15.8 \%$ & $19.6 \%$ & $17.6 \%$ \\
\hline & & Adjusted Residue & -.7 & .7 & \\
\hline \multirow{2}{*}{ Total } & & Occurred & 114 & 102 & 216 \\
\hline & & \% DM in attack & $52.8 \%$ & $47.2 \%$ & $100.0 \%$ \\
\hline
\end{tabular}

Note * Difference found for $p<0.05$.

\section{DISCUSSION}

The aim of the present study was to compare the tactical-technical behavior on the side-out between two distinct situations of reduced volleyball games. Reception results showed that in SIT2, there were better results in technical performance, specifically adjustment and decision making, while in SIT1, effectiveness was higher. There was no difference in efficiency as a function of the situation in which the game was played. Although no studies were found on this subject, it was observed that the court size interferes with the service performance, and the court size interferes with the service power and consequently the service-reception relationship ${ }^{18}$. In this context, it is clear that the technical gesture is conditioned by the momentary tactics and the game unpredictability ${ }^{19}$, and, based on the 
ecological theory, cognition emerges from the organism-environment relationship, which are related to environmental restrictions ${ }^{20,21}$, that is, changes in tactical-technical behavior are dependent on environmental changes. In this context, it could be inferred that when the court presented shorter length, technical and decision-making aspects presented higher rates, while when court is longer, efficiency was higher. In this context, it is possible to infer that shorter court allows better technical performance at reception; however, due to the distance from the actual playing situation, it reduces the action effectiveness.

Regarding setting, it was observed that in SIT2, there were better results in technical performance, adjustment and efficiency, while in SIT1, effectiveness was higher. There was no difference in decision making as a function the situation in which the game was played. These results corroborate literature, since volleyball actions influence subsequent game procedures $^{12,13}$, thus justifying the higher efficacy in SIT1. In addition, differences in court dimensions that influence the player's tactical-technical behavior $^{10}$, may justify the technical performance results. On the other hand, knowing that the adjustment and efficiency criteria are related to the player's posture before ball contact, as well as to the motor performance ${ }^{16,19}$, it may be suggested that in SIT2, higher demand of these technical aspects became necessary, since reception in this situation was less effective compared to SIT1.

The attack analysis showed that in SIT2, there were better results in technical performance, specifically in adjustment and decision making. There was no difference in efficiency and effectiveness as a function of the situation in which the game was played. These results corroborate literature, since volleyball actions are dependent on previous actions ${ }^{12,13}$ and that sports performance is associated with adequate effectiveness in tactical-technical actions ${ }^{19}$.

From the results found, it was observed that environmental restrictions, as well as the interrelationship among game procedures, have led to different tactical-technical behaviors. In this context, the pedagogical strategy of using reduced games for sports teaching ${ }^{3,7,8}$ should be rethought according to the situational constraints inherent to the type of game ${ }^{5,11}$, and court dimensions interfere with tactical-technical learning ${ }^{10}$.

\section{CONCLUSION}

Taken together, the results contributed to a better understanding of changes in the tactical-technical behavior of volleyball players in relation to two different court sizes with the same square footage $(9 \mathrm{~m} 2)$. In this context, the results suggest that court sizing should be considered in the elaboration of the teaching and learning processes in volleyball, and different ecological contexts provide opportunities inherent to the specific game environment. Further studies should be carried out to consolidate knowledge about how pedagogical principles influence the behavior of volleyball players. 


\section{COMPLIANCE WITH ETHICAL STANDARDS}

\section{Funding}

This research did not receive any specific grant from funding agencies in the public, commercial, or not-for-profit sectors. This study was funded by the authors.

\section{Ethical approval}

Ethical approval was obtained from the local Human Research Ethics Committee - Universidade Federal de Goiás and the protocol (no. 2.394.440) was written in accordance with the standards set by the Declaration of Helsinki.

\section{Conflict of interest statement}

The authors have no conflict of interests to declare.

\section{Author Contributions}

Conceived and designed the experiments: Freire AB, Mitre GP, Castro HO, Costa GCT. Performed the experiments: Rocha ACR, Silva Junior AB, Martins LR, Maia MP. Analyzed the data: Costa GCT. Contributed reagents/materials/analysis tools: Rocha ACR, Silva Junior AB, Martins LR, Maia MP. Wrote the paper: Rocha ACR, Freire AB, Mitre GP, Castro HO, Costa GCT.

\section{REFERENCES}

1. Rampinini E, Impellizzeri F, Castagna C, Chamari K, Sassi A, Marcora S. Factors influencing physiological responses to small-sided soccer games. J Sport Sci 2007; 25(6):659-666.

2. Capranica L, Tessitore A, Guidetti L, Figura F. Heart rate and match analysis in pre-pubescent soccer players. J Sport Sci 2001;19(6):379-384.

3. Almeida CH, Ferreira AP, Volossovitch A. Offensive sequences in youth soccer: effects of experience and small-sided games. J Hum Kinet 2013; 36(1), 97-106.

4. Clemente FM, Couceiro M, Martins FM, Mendes R. The usefulness of small-sided games on soccer training. J Phys Educ Sport 2012;12(1):93-102.

5. Travassos B, Gonçalves B, Marcelino R, Monteiro R, Sampaio J. How perceiving additional targets modifies teams' tactical behavior during football small-sided games. Hum Mov Sci 2014;38:241-250.

6. Silva P, Esteves P, Correia V, Davids K, Araújo D, Garganta J. Effects of manipulations of player numbers vs. field dimensions on inter-individual coordination during small-sided games in youth football. Int J Perform Anal Sport 2015;15(2):641-659.

7. Ric A, Torrents C, Gonçalves B, Torres-Ronda L, Sampaio J, Hristovski R. Dynamics of tactical behaviour in association football when manipulating players' space of interaction. PLoS One 2017;12(7):e0180773.

8. Bredt SGT, Morales JCP, Andrade AGP, Torres JO, Peixoto GH, Greco PJ, et al. Space creation dynamics in basketball small-sided games. Percept Mot Skills 2017;1(1):1-15.

9. Lacono AD, Martore D, Zagatto AM, Meckel Y, Sindiani M, Milic M. Effect of contact and non-contact small-sided games on elite handeball players. J Sport Sci 2016;36(1):14-22. 
10. Timmerman E, Farrow D, Savelsbergh G. The effect of manipulating task constraints on game performance in youth field hockey. Sport Sci Coach 2017;12(5):588-594.

11. Serra-Olivares J, González-Villora S, Garcia-López LM, Araújo D. Game-based approaches' pedagogical principles: exploring task constraints in youth soccer. J Hum Kinet 2015;46:251-261.

12. Costa GCT, Afonso J, Barbosa RV, Coutinho P, Mesquita I. Predictors of attack efficacy and attack type in high-level brazilian women's volleyball. Kinesiology 2014;46(2):242-248.

13. Costa GC, Castro HO, Evangelista B, Malheiros L, Greco PJ, Ugrinowitsch H. Predicting factors of zone 4 attack in volleyball. Percept Mot Skills 2017;124(3):621-633.

14. Ericsson A, Charnes N, Feltovich P, Hoffman R. The cambridge handebook of expertise and expert performance. New York: Cambridge University Press; 2006.

15. Collet C, Nascimento JV, Ramos V, Stefanello JMF. Construction and validation of a technical-tactical performance evaluation instrument in volleyball. Rev Bras Cineantropom Desempenho Hum 2011;13(1):43-51.

16. Porath M, Vieira J, Milisted M, Quinaud R. Level of technical-tactical performance of youth volleyball teams. Motri 2016;12(2):8-17.

17. Tabachnick B, Fidell L. Using multivariate statistics. 6th ed. Boston: Allyn \& Bacon; 2013.

18. Trajković N, Krističević T, Sporiš G. Small-sided games vs. instructional training for improving skill accuracy in young female volleyball players. ACTA Kin 2017;11(2):72-76.

19. Salles WN, Collet C, Porath M, Milistetd M, Nascimento JV. Factors associated to performance efficacy of technical-tactical actions in volleyball. Rev Bras Cineantropom Desempenho Hum 2017;19(1):74-83.

20. Seifert L, Araujo D, Komar J, Davids K. Understanding constraints on sport performance from the complexity sciences paradigm: an ecological dynamics framework. Hum Mov Sci 2017;56:178-180.

21. Davids K, Araújo D, Hristovski R, Serre NB, Button C, Passos P. Complex systems in sport. Routledge, Taylor \& Francis Group, London, UK; 2014.

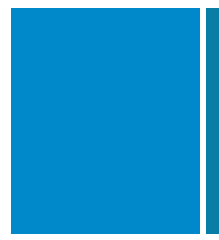

Corresponding author

Gustavo De Conti Teixeira Costa

Faculdade de Educação Física e Dança

Universidade Federal de Goiás, Campus Samambaia

Avenida Esperança s/n, Goiânia, Goiás, Brasil.

CEP: 74.690-900.

Email:conti02@ufg.br 